\title{
UPAYA GURU PAI DALAM PENINGKATAN KECERDASAN EMOSIONAL DAN SPIRITUAL PESERTA DIDIK DI SMAN 1 BOJONEGORO
}

\author{
Hasanatul Mutmainah \\ STIT Al Urwatul Wutsqo Jombang \\ hasanatulmutmainah15@gmail.com
}

\begin{abstract}
Abstrak
"Kasus kenakalan remaja seperti tawuran pelajar bukan hal asing lagi di masyarakat. Bagi masyarakat, guru dianggap berperan besar dalam penanaman nilai - nilai emosional dan spiritual sebagai penanggulangan kemerosotan moral generasi bangsa, utamanya guru Pendidikan Agama Islam. Dengan menggunakan penelitian lapangan dan pendekatan kualitatif, ada dua fokus utama yang disajikan yaitu upaya dilakukan guru PAI di SMAN 1 Bojonegoro dalam peningkatan kecerdasan emosional dan spiritual, dan faktor pendukung serta penghambat yang dirasakan oleh guru PAI. Akan di paparkan dalam penelitian ini berbagai upaya guru PAI dalam peningkatkan kecerdasan emosional dan spiritual peserta didik dengan menyelenggarakan pembelajaran, pengembangan, serta evaluasi pembelajaran PAI."
\end{abstract}

Kata kunci: Guru PAI, Kecerdasan Emosional dan Spiritual

\section{Pendahuluan}

Kualitas sumber daya manusia sebuah negara yang masih berkembang menjadi suatu yang urgen. Keunggulan suatu bangsa tidak lagi bertumpu pada kekayaan alam, melainkan pada keunggulan sumber daya manusia. Dalam hal ini, guru dianggap mampu menjawab tantangan-tantangan yang sangat cepat. UU No. 20 tahun 2003 tentang Sistem Pendidikan Nasional berfungsi untuk mengembangkan kemampuan dan membentuk watak serta peradaban bangsa yang bermartabat dalam rangka mencerdaskan kehidupan bangsa. Tujuan arti sistem pendidikan tersebut untuk menumbuhkembangkan peserta didik agar menjadi manusia yang beriman dan bertakwa kepada Tuhan Yang Maha Esa, berakhlak mulia, sehat, berilmu, cakap, kreatif, mandiri, dan menjadi warga negara yang demokratis serta bertanggung jawab. ${ }^{1}$

Abdurrahman al-Nahlawi, membagi tugas guru yang utama dengan dua bagian. Pertama, penyucian, pengembangan, pembersihan, dan pengangkatan jiwa kepada penciptanya,

\footnotetext{
${ }^{1}$ Undang-Undang SISDIKNAS 2003.
} 
menjauhkan dari kejahatan dan menjaga agar selalu berada dalam fitrahnya. Kedua, pengajaran, yakni pengalihan berbagai pengetahuan dan akidah kepada akal dan hati kaum mukmin, agar mereka merealisasikannya dalam tingkah laku dan kehidupan. ${ }^{2}$ Paparan diatas menjelaskan bahwa peran seorang guru sebagai pendidik tidak bisa asal-asalan atau hanya bermodal kapur tulis dan menjelaskan didepan para peserta didik, tetapi harus memenuhi aspek pedagogis, psikologis, dan didaktis secara bersamaan. Dari kedua tugas tersebut, peran guru bukan hanya membuat peserta didik menjadi sosok yang cerdas secara intelektual saja, tetapi dari segi emosi dan spiritual.

Menurut Goleman, emosi merujuk pada suatu perasaan dan pikiran yang khas, suatu keadaan biologis dan psikologis dan serangkaian kecenderungan untuk bertindak. ${ }^{3}$ Emosi dapat berupa kebencian atau teror yang berakhir pada perkelahian. Akan tetapi emosi juga dapat berupa kasih sayang, perhatian, cinta dan ambisi. ${ }^{4}$ Berarti emosi tidak terbatas pada perbuatan negatif yang brutal, tetapi juga menyangkut perbuatan positif yang dapat menumbuhkan hubungan yang harmonis antar sesama.

Selain emosi, spiritualitas seseorang sangat berpengaruh dalam kehidupan sehariharinya. Seseorang yang memiliki spiritualitas yang baik tentunya mengetahui perkara yang haq dan batil. Adanya pelajaran Pendidikan Agama Islam (PAI) bertugas menginternalisasikan (menanamkan) nilai-nilai Islam mengembangkan anak didik agar mampu melakukan pengalaman nilai-nilai secara dinamis dan fleksibel dalam batas-batas konfigurasi identitas wahyu Tuhan. Berarti guru PAI secara optimal harus mampu mendidik anak didiknya agar memiliki kedewasaan dan kematangan dalam beriman dan bertakwa serta mengamalkan hasil pendidikan yang diperolehnya, tujuannya yaitu menjadi pemikir sekaligus pengamal ajaran Islam yang dialogis terhadap perkembangan zaman. ${ }^{5}$

Meski zaman sudah maju, beberapa realita yang ada seperti tawuran antar remaja, pelecehan dan banyak kasus lain semakin marak serta tidak bisa dianggap remeh. Hal ini membuat pendidik khawatir generasi penerus akan terpuruk, baik dari segi peradaban, pemikiran, maupun moralitas bangsa itu sendiri. Hal tersebut hanya bisa ditanggulangi jika generasi memiliki pengendalian dan kesadaran diri seperti memiliki kecerdasan emosional dan spiritual. Jika generasi telah menyadari peran dirinya dan memahami betul perkara yang

\footnotetext{
2 Ngainun Naim, Menjadi Guru Inspiratif Memberdayakan Dan Mengubah Jalan Hidup Peserta didik. (Yogyakarta: Pustaka Pelajar, 2009), 17.

${ }^{3}$ Daniel Goleman, Emotional Intelligence, terj., (Jakarta: Gramedia Pustaka Utama, 2007), 43.

${ }^{4}$ Oemar Hamalik, Psikologi Belajar dan Mengajar (Bandung: Sinar Baru Algensindo, 2004), 53.

${ }^{5}$ HM. Arifin, Filsafat Pendidikan Islam (Jakarta: Bumi Aksara, 2010), 122.
} 
baik dan buruk maka tidak larut dalam perubahan yang negatif, karena telah memiliki benteng yang cukup kokoh agar tidak mudah terpengaruh perilaku menyimpang.

Peneliti mengambil setting di SMAN 1 Bojonegoro yang merupakan sekolah unggulan di kota Bojonegoro. Sekolah yang menjadi salah satu sekolah rujukan tersebut memiliki guru dan peserta didik berkemampuan unggul. Ada kekhawatiran muncul karena peserta didik kemungkinan unggul hanya sebatas intelektualnya, sedangkan secara emosional dan spiritual masih kurang. Berdasarkan paparan diatas, maka muncul uraian bagaimana upaya guru PAI dalam peningkatan kecerdasan emosional dan spiritual peserta didik di SMAN 1 Bojonegoro? Apa faktor pendukung dan penghambat dari upaya guru PAI dalam peningkatan kecerdasan emosional dan spiritual peserta didik di SMAN 1 Bojonegoro?

Pendekatan yang digunakan adalah pendekatan kualitatif. Sedangkan jenis penelitian yang digunakan adalah penelitian lapangan (field research). Teknik pengumpulan data yang digunakan adalah observasi partisipatif, wawancara, dan dokumentasi. Penelitian ini menggunakan analisis deskripsi (deskriptif analitik) dengan langkah-langkah data reduction, data display, dan conclusion drawing / verification. Teknik pengujian keabsahan data yang digunakan adalah perpanjangan keikutsertaan, ketekunan observasi, dan triangulasi (sumber, waktu, teknik).

\section{Guru Pendidikan Agama Islam (PAI)}

Pendidikan sebagai suatu sistem yang memiliki komponen-komponen yang saling mempengaruhi. Komponen yang sangat penting dari komponen lainnya dalam pendidikan adalah guru. Dikatakan demikian sebab berpengaruh besar dalam usaha mencapai pendidikan. ${ }^{6}$ Guru dalam Kamus Besar Bahasa Indonesia berarti orang yang pekerjaannya (mata pencahariannya, profesinya) mengajar. ${ }^{7}$

Salah satu faktor yang paling menentukan dalam proses pembelajaran di kelas adalah guru. Tugas guru yang paling utama adalah mengajar dan mendidik. Sebagai pengajar, guru besrperanan aktif (medium) antara peserta didik dengan ilmu pengetahuan. ${ }^{8}$ Secara umum dapat dikatakan bahwa tugas dan tanggung jawab yang harus dilaksanakan oleh guru adalah mengajak orang lain berbuat baik. Tugas tersebut identik dengan dakwah islamiyah yang

\footnotetext{
${ }^{6}$ Kartilawati dan Mawaddatan Warohmah, "Profesionalisme Guru Pendidikan Agama Islam di Era Teknologi Informasi dan Komunikasi,” TA’DIB, 19 (Juni, 2014), 143 - 144.

${ }^{7}$ Depdiknas, Kamus Bahasa Indonesia (Jakarta: Pusat Bahasa, 2008), 497.

${ }^{8}$ Shabir, "Kedudukan Guru Sebagai Pendidik," AULADUNA, 2 (Desember, 2015), 226.
} 
bertujuan mengajak umat Islam untuk berbuat baik. Allah swt. berfirman di dalam Q.S. Ali Imran/3: 104:

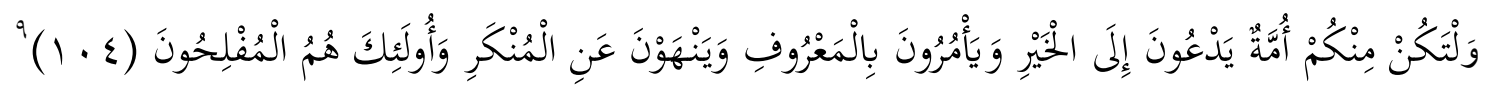

Artinya: "Dan hendaklah ada di antara kamu segolongan umat yang menyeru kepada kebajikan, menyuruh kepada yang ma'ruf dan mencegah dari yang munkar merekalah orangorang yang beruntung. "10

Dari ayat diatas segolongan umat hendaklah menyeru dalam kebajikan, menyuruh yang ma'ruf dan mencegah perkara yang mungkar diartikan lebih mendalam sebagai tugas guru khususnya guru PAI. Ramayulis menuliskan dalam bukunya ada beberapa teknik mengajar guru PAI, yaitu mendidik melalui keteladanan, mendidik melalui kebiasaan, mendidik melalui nasihat dan cerita, mendidik melaui disiplin, mendidik melalui partisipatif, dan mendidik melalui pemeliharaan. ${ }^{11}$

\section{Kecerdasan Emosional/Emotional Quotient (EQ)}

Istilah $E Q$ (Kecerdasan Emosional) pertama kali dilontarkan oleh Salovey dan Mayer, namun konsep $E Q$ dipopulerkan oleh Goleman pada tahun 1995. Jordan mengemukakan bahwa kecerdasan emosional memegang peranan penting untuk memprediksi kinerja suatu tim. Segal mengatakan bahwa emosi dan akal adalah dua bagian dari satu keseluruhan, dimana wilayah $E Q$ adalah hubungan pribadi dan antarpribadi. $E Q$ bertanggung jawab atas harga diri, kesadaran diri, kepekaan sosial, dan kemampuan adaptasi sosial. Sementara itu, Reuven Bar-On menjabarkan $E Q$ ini ke dalam lima domain yang terdiri dari domain intrapribadi, antar pribadi, pengendalian stres, penyesuaian diri, dan suasana hati umum. Dengan demikian dapat disimpulkan bahwa $E Q$ adalah kecerdasan yang berhubungan dengan kemampuan pribadi dan kemampuan sosial. ${ }^{12}$

Menurut penelitian Daniel Goleman seorang psikolog dari Harvard menunjukkan bahwa manusia mempunyai suatu jenis potensi dasar yang lain, yaitu kecerdasan emosional. Menurut pendapatnya bahwa kecerdasan akan dapat secara efektif apabila seorang mampu memfungsikan kecerdasan emosinya. Kecerdasan emosional dapat dilatih, dipelajari, dan dikembangkan pada masa kanak-kanak, sehingga masih ada peluang untuk

\footnotetext{
${ }^{9}$ QS. Ali Imran (3): 104.

${ }^{10}$ Al Qur'an Terjemah Departemen Agama, Al-Qur'an Hafalan dan Terjemah (Jakarta: Almahira, 2015), 63.

${ }^{11}$ Ramayulis, Ilmu Pendidikan Islam (Jakarta: Kalam Mulia, 2011), 198 - 201.

12 Ardana dkk, "Kecerdasan Intelektual, Kecerdasan Emosional, Kecerdasan Spiritual, Dan Kesehatan Fisik Untuk Memprediksi Prestasi Belajar Mahasiswa Akuntansi," Jurnal Akuntansi Universitas Tarumanagara Jakarta, 17 (September, 2003), 443 - 444.
} 
menumbuhkembangkan dan meningkatkannya untuk memberikan sumbangan bagi sukses hidup seseorang. ${ }^{13}$

Menurut Goleman kecerdasan emosional adalah kemampuan seseorang mengatur kehidupan emosinya dengan intelegensi (to manage ouremotional life with intellegence), menjaga keselarasan emosi dan pengungkapannya (the appropriateness of emotion and it's expression) melalui keterampilan kesadaran diri, pengendalian diri, motivasi diri, empati dan keterampilan sosial. ${ }^{14}$ Pertumbuhan EQ dipengaruhi oleh beberapa faktor, antara lain: lingkungan, keluarga, dan faktor kematangan. ${ }^{15}$

Salovey dan Meyer mendefinisikan kecerdasan emosional sebagai himpunan bagian dari kecerdasan sosial yang melibatkan kemampuan memantau perasaan sosial pada orang lain, memilah - milah dan menggunakan informasi untuk membimbing pikiran dan tindakan. ${ }^{16}$ Kecerdasan emosional sangat dipengaruhi oleh lingkungan, tidak bersifat menetap, dapat berubah - ubah setiap saat. Peranan lingkungan terutama orang tua pada masa kanak-kanak sangat mempengaruhi dalam pembentukan kecerdasan emosional. Keterampilan EQ bukanlah lawan dari keterampilan $I Q$, namun keduanya berinteraksi secara dinamis, baik tingkatan konseptual maupun didunia nyata. Selain itu $E Q$ tidak begitu dipengaruhi oleh faktor keturunan. ${ }^{17}$

Dari uraian di atas, dapat peneliti simpulkan bahwa pada prinsipnya setiap komponen pembangunan kecerdasan emosional adalah lingkungan dan pengalaman. Jika ditarik kesimpulan dalam dunia pendidikan, maka diantarannya anak dapat dididik, dilatih, dan senantiasa diperkaya pengalamannya dalam berbagai suasana emosi. Membangun kesadaran tentang sikap moral mentalitas, menyatunya kata dan perbuatan, melalui pembelajaran yang baik dan benar. Sehingga peserta didik tidak hanya cerdas dalam berfikir, tetapi juga bersifat cerdas emosi dan cerdas budi, kreatif, dan istiqamah.

\section{Kecerdasan Spiritual/Spiritual Quotient (SQ)}

Kecerdasan spiritual (SQ) adalah fakultas dimensi non material jiwa manusia. Ibaratkan seperti intan yang belum terasah, yang dimiliki oleh manusia. Setiap individu harus mengenalinya sehingga mengkilap dengan tekad yang besar dan menggunakannya untuk

\footnotetext{
${ }^{13}$ Daniel Goleman, Emotional Intellegence terj., (Jakarta: Gramedia Pustaka Utama, 2007), 18.

${ }^{14}$ Ibid.

${ }^{15}$ Daniel Goleman, Emotional Intelegence.., 51 - 54.

${ }^{16}$ Herwati, "Emotional Spiritual Quotient dan Relevansinya terhadap Pendidikan Agama Islam," (Tesis, UIN Maulana Malik Ibrahim, Malang, 2016), 25.

${ }^{17}$ Muhammad Utsman Najati, Belajar EQ dan SQ dari Sunnah terj. (Jakarta: Hikmah, 2004), 6.
} 
memperoleh kebahagiaan abadi. Seperti dua bentuk kecerdasan lainnya (IQ dan $E Q$ ), kecerdasan spiritual dapat dan diturunkan. Kemampuannya untuk diturunkan tampaknya tidak terbatas. ${ }^{18}$

M. Utsman Najati mengemukakan bahwa dorongan spiritual adalah dorongan yang berhubungan aspek spiritual dalam diri manusia, seperti dorongan untuk beragama, takwa, cinta kebajikan, kebenaran dan keadilan, benci terhadap kejahatan, kebathilan dan kedzaliman. Sependapat dengan hal tersebut, dikutip dalam bukunya M. Utsman Najati, A. Maslow mengatakan bahwa kebutuhan spiritual manusia merupakan kebutuhan alami, yang integritas perkembangan dan kematangan kepribadian individu sangat tergantung pada pemenuhan kebutuhan manusia tersebut. ${ }^{19}$

Madhu Jain dan Prema Purohit mencoba meyakinkan bahwa hidup menjadi manusia (human beings) berarti menjalani kehidupan yang bersifat spiritual. ${ }^{20}$ Dari beberapa penjelasan tentang $S Q$ di atas, dapat disimpulkan bahwa $S Q$ adalah kemampuan manusia untuk menghayati keterhubungan dirinya dengan kekuatan tak terbatas (Tuhan), serta menyadari tingkat kebermaknaan hidup dan sifat-sifat keilahian yang ada di dalam diri manusia.

Ciri-ciri manusia yang memiliki kecerdasan spiritual berdasarkan teori Zohar dan Marshall dan Sinetar yaitu: memiliki kesadaran diri, memiliki visi, bersikap fleksibel, berpandangan holistic, melakukan perubahan, sumber inspirasi, dan refleksi diri. ${ }^{21}$ Apabila seseorang ingin melakukan suatu keinginan, kemauan dan tindakan, tentu saja tidak semudah yang dibayangkan. Hal tersebut tidak lepas dari adanya suatu hambatan dalam melakukannya. Begitu juga jika seseorang ingin memiliki kecerdasan spiritual, maka tidak akan terlepas pula dengan berbagai hambatan. Hambatan-hambatan tersebut diantaranya prasangka negatif, pengaruh prinsip hidup, pengaruh pengalaman, pengaruh kepentingan, pengaruh sudut pandang, pengaruh pembanding, dan pengaruh literatur. ${ }^{22}$

Sehebat apapun manusia dengan kecerdasan intelektual maupun kecerdasan emosional, pada saat-saat tertentu melalui pertimbangan afektif, kognitif, dan konatifnya,

\footnotetext{
${ }^{18}$ Sukidi, Kecerdasan Spiritual; Mengapa SQ Lebih Penting dari IQ dan EQ, (Jakarta: Gramedia Pustaka Utama, 2002), 77.

${ }^{19}$ M. Usman Najati, Al-Qur'an dan Psikologi, Terj. Ade Asnawi S, (Jakarta: Asas Pustaka, 2001), 15.

${ }^{20}$ Ardana dkk, "Kecerdasan Intelektual, Kecerdasan Emosional, Kecerdasan Spiritual, Dan Kesehatan Fisik Untuk Memprediksi Prestasi Belajar Mahasiswa Akuntansi,” Jurnal Akuntansi, 17 (September, 2003), 445 446.

${ }^{21}$ Nurdiansyah Junifar, "Pengaruh Kecerdasan Emosional, Kecerdasan Spiritual, Dan Perilaku Belajar Terhadap Tingkat Pemahaman Akuntansi," Jurnal Ilmu dan Riset Sekolah Tinggi Ilmu Ekonomi Indonesia (STIESIA) Surabaya, 5 (2015), 5.

${ }^{22}$ Agustian, Rahasia Sukses Membangun, 74.
} 
manusia akan meyakini dan menerima tanpa keraguan bahwa di luar dirinya ada sesuatu kekuatan yang Maha Agung yang melebihi apapun, termasuk dirinya. Menurut Danah Zohar, bahwa $I Q$ bekerja untuk melihat keluar (mata pikiran) dan $E Q$ bekerja mengolah yang di dalam (telinga perasaan), maka $S Q$ menunjuk pada kondisi pusat diri. Orang yang ber- $S Q$ tinggi memaknai penderitaan hidup dengan memberi makna positif pada setiap peristiwa, masalah, bahkan penderitaan yang dialaminya. Dengan memberi makna yang positif itu, seseorang mampu membangkitkan jiwanya dan melakukan perbuatan dan tindakan yang positif. $^{23}$

$S Q$ menyadarkan seseorang akan tujuan hidup dan pemaknaan kehidupan yang dijalaninya. Hidup memiliki arah dan tujuan, dan setiap kehidupan memiliki pemaknaan yang tidak sekedar makna - makna yang bersifat duniawi. Kecerdasan ini menjadi pedoman, arah dan tujuan hidup untuk menjalani kehidupan.

\section{Upaya Guru PAI dalam Peningkatan Kecerdasan Emosional dan Spiritual Peserta Didik di SMAN 1 Bojonegoro}

SMAN 1 Bojonegoro memiliki citra moral yang menggambarkan profil sekolah yang diinginkan di masa datang dan diwujudkan dalam visi sekolah yaitu "Unggul dalam ilmu pengetahuan berlandaskan iman dan takwa serta mampu bersaing secara global yang berwawasan lingkungan hidup." Salah satu perwujudannya yaitu dilakukan usaha menumbuhkan penghayatan dan semangat pengamalan terhadap ajaran agama. Dengan pendidikan agama dimaksudkan untuk peningkatan potensi kecerdasan emosional dan spiritual serta membentuk peserta didik agar menjadi manusia yang beriman dan bertakwa kepada Tuhan yang Maha Esa dan berakhlak mulia.

Peningkatan kecerdasan emosional dan spiritual mencakup pengamalan, pemahaman, dan penanaman nilai-nilai keagamaan, serta pengamalan nilai-nilai tersebut dalam kehidupan individual maupun kolektif kemasyarakatan. Peningkatan kecerdasan emosional dan spiritual tersebut pada akhirnya bertujuan pada optimalisasi berbagai potensi yang dimiliki manusia yang aktualisasinya mencerminkan harkat dan martabatnya sebagai makhluk Tuhan. ${ }^{24}$

Guru PAI SMAN 1 Bojonegoro selalu berusaha mengaktualisasikan serta mengembangkan pendidikan, terutama dalam hal pendidikan emosional, agama ataupun spiritual dengan berbagai cara. Hal tersebut tidak lepas dari membuat perencanaan meliputi

\footnotetext{
${ }^{23}$ Herawati, "Emosional Spiritual Qoutient ...," 50.

${ }^{24}$ Asmuan Sahlan, Mewujudkan budaya religious di sekolah Upaya pengembangan PAI dari teori ke aksi, ( Malang: UIN Maliki Press, 2010 ), 17
} 
melengkapi perangkat pembelajaran, melaksanakan pembelajaran dengan berbagai metode yang sesuai, melaksanakan evaluasi berkelanjutan yang berpusat pada pembelajaran dan sebagainya. Pentingnya perencanaan seperti yang dijelaskan dalam Undang-undang RI No. 20 Tahun 2003 tentang Sistem Pendidikan Nasional pasal 1 menjelaskan bahwa pendidikan adalah usaha sadar dan terencana untuk mewujudkan suasana belajar dan proses pembelajaran dengan harapan agar peserta didik secara aktif mampu mengembangkan potensi dirinya. ${ }^{25}$

Pada tahap perencanaan, guru sebagai penentu keberhasilan upaya pendidikan, sehingga guru berperan penting dalam pembentukan kecerdasan emosional dan spiritual, bahasa yang santun dapat memberikan dampak positif kepada peserta didik, artinya diksi yang digunakan guru berpegaruh terhadap pembentukan kecerdasan emosional dan spiritual. Pemilihan diksi yang baik bisa membuat peserta didik terpengaruh untuk melakukan perubahan menjadi semakin baik sehingga mempermudah melaksanakan tujuan pendidikan.

Keraf mengatakan bahwa dengan ketepatan pilihan kata akan menimbulkan gagasan gagasan yangg tepat pada pendengar. Kata-kata ibarat "pakaian" yang dipakai oleh pikiran kita. Tiap kata memiliki “jiwa”. Setiap anggota masyarakat harus mengetahui "jiwa”, agar ia dapat menggerakkan orang lain dengan "jiwa" dari kata-kata yang dapat digunakannya. ${ }^{26}$

Tahap pelaksanaan pembelajaran ada beberapa pendekatan yang dilakukan, antara lain: ${ }^{27}$ pendekatan pengalaman, pendekatan pembiasaan, pendekatan emosional, pendekatan rasional, pendekatan fungsional, pendekatan keteladanan, dan pendekatan terpadu. Pelaksanaan pembelajaran PAI di SMAN 1 Bojonegoro salah satunya menggunakan metode keteladanan. Pada pelaksanaan pembelajaran PAI juga dilakukan improvisasi dan pengembangan - pengembangan kegiatan belajar mengajar. Hal tersebut teraplikasi dalam tindakan nyata seperti sholat dhuha, jama'ah dhuhur, dan sebagainya. Guru menggunakan bahasa yang mudah diterima sehingga hati membenarkan dan melaksanakan dengan kesadaran tanpa paksaan dan tidak mempermasalahkan perkembangan zaman di era modern.

Berkembangnya era modernisasi membuat guru PAI harus pandai dalam menyikapi pertanyaan peserta didik yang semakin bervariasi. Agar peserta didik tidak salah persepsi, maka guru menjelaskan dengan rinci dan memberikan tanggapan dari berbagai sudut pandang khususnya pandangan Islam. Adanya trend seperti rebonding rambut, jilboobs dan seterusnya membuat dampak yang berarti dikalangan masyarakat awam, menyiasatinya yaitu

\footnotetext{
${ }^{25}$ UU No. 20 tahun 2003.

${ }^{26}$ Keraf, Etika Lingkungan Hidup (Jakarta: Kompes Media Nusantara, 2010), 21 - 23.

${ }^{27}$ Ramayulis, Ilmu Pendidikan Islam (Jakarta: Kalam Mulia, 2011), 169 - 175.
} 
memberikan kesadaran kepada peserta didik, sebab lingkungan juga berpengaruh, baik keluarga atau masyarakat. Guru PAI berupaya dengan cara menanamkan kecerdasan emosional dan spiritual.

Kecerdasan spiritual dipengaruhi sumber kecerdasan itu sendiri (God Spot), potensi qalbu (hati nurani), dan kehendak nafsu. Sedangkan secara umum faktor utama yang mempengaruhi kecerdasan spiritual seseorang adalah faktor lingkungan yang lebih khususnya didominasi oleh peran orang tua dalam membina kecerdasan anak dalam keluarga. Manusia yang memiliki $S Q$ tinggi cenderung akan lebih bertahan hidup dari pada orang yang memiliki $S Q$ rendah. $^{28}$

Semakin sering potensi hati diolah, maka akan semakin meningkatkan kedewasaan, dengan demikian diharapkan bisa membantu dalam peningkatan emosional dan spiritual peserta didik. SMAN 1 Bojonegoro dalam meningkatkan ESQ juga melaksanakan pembiasaan-pembiasaan yang diharapkan bisa melatih peserta didik menjadi lebih baik dan terarah, baik pembiasaan di dalam kelas maupun di luar kelas.

M. Utsman Najati mengemukakan bahwa dorongan spiritual adalah dorongan yang berhubungan aspek dalam diri manusia, seperti dorongan untuk beragama, takwa, cinta kebajikan, kebenaran dan keadilan, benci terhadap kejahatan, kebathilan dan kedzaliman. Sependapat dengan hal tersebut, dikutip dalam bukunya M. Utsman Najati, A. Maslow mengatakan bahwa kebutuhan spiritual manusia merupakan kebutuhan alami, yang integritas perkembangan dan kematangan kepribadian individu sangat tergantung pada pemenuhan kebutuhan tersebut. ${ }^{29}$ Sehingga intensitas perkembangan spiritual tergantung seberapa banyak pemenuhan kebutuhan alami tersebut.

Pemenuhan kebutuhan alami yang diterapkan SMAN 1 Bojonegoro yaitu dengan melakukan pengembangan dan pengamalan pembelajaran PAI seperti sholat dhuha setiap pagi, murottal qur'an dan literasi, Jum'at bersih, kajian malam Jum'at, keputrian, tafakur alam, serta tahfidz. Pengembangan tersebut bertujuan meningkatkan kecerdasan emosional dan spiritual peserta didik dengan melatih mental. Contohnya sholat dhuha dengan tujuan meningkatkan ubudiyyah peserta didik yang sesuai dengan aspek dalam PAI sendiri dengan tanpa jadwal dan paksaan. Hal tersebut menandakan peserta didik secara alami bisa memaknai pentingnya sholat dhuha yang dilaksanakannya.

\footnotetext{
${ }^{28}$ Ary Ginanjar Agustian, Rahasia Sukses Membangun Kecerdasan Emosi Dan Spiritual, (Jakarta: Arga Wijaya Persada, 2001), 56.

${ }^{29}$ M. Usman Najati, Al-Qur'an dan Psikologi, Terj. Ade Asnawi S, (Jakarta: Asas Pustaka, 2001), 15.
} 
Zohar dan Marshall menjelaskan bahwa spiritualitas lebih berkaitan dengan pencerahan jiwa. Orang yang memiliki kecerdasan spiritual tinggi mampu memaknai hidup dengan memberi makna positif pada setiap peristiwa, masalah, bahkan penderitaan yang dialaminya. Dengan memberi makna yang positif akan mampu membangkitkan jiwa dan melakukan perbuatan dan tindakan yang positif. Sehingga tidak ada lagi prasangka buruk terhadap apa yang terjadi, dan secara tidak langsung memenuhi konsep iman terhadap qadha dan qadar.

Permendikbud no 60 tahun 2014 bahwa Pendidikan Agama Islam dan Budi Pekerti adalah pendidikan yang ditujukan untuk dapat menyerasikan, menyelaraskan dan menyeimbangkan antara iman, Islam, dan ihsan yang diwujudkan dalam hubungan manusia dengan Allah Swt, manusia dengan diri sendiri, manusia dengan sesama, dan manusia dengan lingkungan alam. $^{30}$

Dari tujuan pendidikan agama Islam diatas, dapat dikatakan bahwa tujuan pendidikan agama Islam yaitu menjadikan manusia yang lebih baik. Senada dengan ungkapan Marimba yang mengatakan tujuan pendidikan agama Islam adalah terciptanya orang yang berkepribadian muslim, membentuk manusia berakhlak mulia, dan menjadikan manusia yang sempurna (insan kamil). ${ }^{31}$ Hal tersebut termasuk refleksi dari kecerdasan emosional dan spiritual yang terdapat dalam nilai - nilai Islam.

Nilai - nilai emosional dan spiritual dalam kurikulum telah diformat sedemikian rupa, sehingga penilaian dalam melaksanakan pendidikan agama Islam tersebut bisa lebih spesifik mengetahui bagaimana tingkat kemampuan siswa dalam memposisikan dirinya dalam kehidupan dengan berdasar pada sikap emosional dan spiritual. Penilaian tersebut tercermin dalam kegiatan keseharian seperti hubungan dengan sesama, hubungan dengan Tuhan, hubungan dengan lingkungan, dan hubungan dengan dirinya sendiri. Dilakukan juga pemantauan terhadap kegiatan pengembangan PAI, disamping penilaian yang secara murni dari kurikulum. Dapat dilihatlah pengaplikasian ESQ dalam perbuatan seperti sholat, murottal qur'an, tahfidz, dan sebagainya.

Kurikulum 2013 membagi kompetensi sikap menjadi dua, yaitu sikap spiritual yang terkait dengan pembentukan peserta didik yang beriman dan bertakwa, dan sikap sosial yang terkait dengan pembentukan peserta didik yang berakhlak mulia, mandiri, demokratis, dan bertanggung jawab. Sikap spiritual sebagai perwujudan dari menguatnya interaksi vertikal

\footnotetext{
${ }^{30}$ Peraturan Menteri Pendidikan Dan Kebudayaan Nomor 60 Tahun 2014 Tentang Kurikulum 2013 Sekolah Menengah Atas/Madrasah Aliyah, 1.

${ }^{31}$ Katni, Pengembangan Kurikulum PAI (Surabaya: Kopertais IV Press, 2015), 137.
} 
dengan Tuhan Yang Maha Esa, sedangkan sikap sosial sebagai perwujudan eksistensi kesadaran dalam upaya mewujudkan harmoni kehidupan. Dari beberapa sikap itu sendiri memiliki tolak ukur masing - masing, sehingga untuk mengetahui seberapa jauh tercapainya tujuan pendidikan perlu dilakukan evaluasi.

Evaluasi juga merupakan suatu tindakan atau suatu proses untuk menentukan nilai dari sesuatu. Evaluasi dalam pendidikan adalah suatu proses dalam usaha untuk mengumpulkan informasi yang dapat digunakan sebagai bahan pertimbangan untuk membuat keputusan, perlu tidaknya memperbaiki system pembelajaran sesuai dengan tujuan yang akan ditetapkan. $^{32}$

Evaluasi pembelajaran yang dilakukan di SMAN 1 Bojonegoro disesuaikan dengan kurikulum yang berlaku yaitu kurikulum 2013. Adanya sikap jujur, amanah, dan seterusnya tidak hanya sekedar diajarkan dalam ranah teori saja, tetapi diaplikasikan dalam keseharian, dengan demikian jika menguasai seluruh kriteria dalam penilaian maka diharapkan semakin meningkat pula kecerdasan emosional dan spiritual peserta didik. Menurut Robert A. Emmons, ada lima karakteristik orang yang cerdas secara spiritual yaitu kemampuan untuk mengalami tingkat kesadaran yang memuncak, kemampuan untuk mensakralkan pengalaman sehari-hari, kemampuan untuk menggunakan sumber-sumber spiritual buat menyelesaikan masalah dan kemampuan untuk berbuat baik. ${ }^{33}$

Adapun penilaian secara keseluruhan terhadap pembelajaran PAI bisa dilihat dari keseharian peserta didik. Kurang lebih $75 \%$ dari keseharian peserta didik di sekolah dinilai baik. Peserta didik memiliki kepekaan terhadap kondisi sekitar, peserta didik juga dinilai bisa mengendalikan emosinya sendiri. Selain itu semakin meningkat perkembangan dan pengetahuan tentang masalah keagamaan, masalah kehidupan yang berhubungan dengan agama, baik al Qur'an, fikih, akhlak, maupun sejarah Islam. Dengan adanya kegiatan seperti Kajian Malam Jum'at dan Keputrian sangat membantu dalam menambah wawasan keagamaan peserta didik untuk meningkatkan kecerdasan emosional dan spiritual.

Ciri-ciri orang yang memiliki kecerdasan spiritual berdasarkan teori Zohar dan Marshall dan Sinetar yaitu memiliki kesadaran diri, memiliki visi, bersikap fleksibel, berpandangan holistik, melakukan perubahan, sumber inspirasi, dan refleksi diri. ${ }^{34}$ Seseorang yang memiliki

\footnotetext{
${ }^{32}$ Muhammad Zaini, Pengembangan Kurikulum: Konsep Implementasi Evaluasi dan Inovasi, (Yogyakarta: Teras, 2009 ),142-143.

${ }^{33}$ Herawati, 46.

${ }^{34}$ Nurdiansyah Junifar, "Pengaruh Kecerdasan Emosional, Kecerdasan Spiritual, Dan Perilaku Belajar Terhadap Tingkat Pemahaman Akuntansi," Jurnal Ilmu dan Riset Sekolah Tinggi Ilmu Ekonomi Indonesia (STIESIA) Surabaya, 5 (2015), 5.
} 
emosional yang baik, salah satu cirinya mempunyai kepekaan perasaan untuk memahami, mengenali, merasakan, mengelola, dan memimpin perasaan sendiri dan orang lain serta mengaplikasikannya dalam kehidupan pribadi dan sosial. Hal tersebut dilihat di lapangan olahraga SMAN 1 Bojonegoro, ketika jam istirahat ada beberapa peserta didik berseragam olahraga gotong - royong memindahkan ring basket karena lapangan akan dibenahi.

Goleman juga membagi kecerdasan emosional menjadi lima bagian yaitu tiga komponen berupa kompetensi emosional (pengenalan diri, pengendalian diri dan motivasi) dan dua komponen berupa kompetensi sosial (empati dan keterampilan sosial). Lima komponen kecerdasan emosional tersebut adalah Pengenalan diri, pengendalian diri, motivasi, empati, dan ketrampilan sosial (social skills). ${ }^{35}$

Dari uraian di atas, dapat peneliti simpulkan bahwa pada prinsipnya setiap komponen pembangunan kecerdasan emosional dan spiritual yaitu kepekaan yang diperoleh dari pelatihan dan pengalaman, serta mampu memaknai dan mengambil tindakan dari setiap kejadian yang dialami dengan positif. Tindakan atau ekspresi seseorang adalah pilihan dari individu tersebut berdasarkan pengalamannya baik secara emosional maupun spiritual. Bisa saja seseorang marah ketika dikecewakan, tapi ada juga yang bersikap biasa dan mengambil sisi positifnya. Terlalu sayang jika energi habis untuk perbuatan sia - sia, bisa saja menggunakan waktu untuk membaca ataupun mendengarkan murottal sehingga bisa menenangkan hati dan pikiran.

Setiap pagi selama tiga hari di SMAN 1 Bojonegoro terdapat rutinitas membaca al Qur'an sebelum pelajaran pertama (15 menit) serta tiga hari lainnya untuk membaca buku non pelajaran, sehingga menambah wawasan peserta didik dan tentunya didampingi oleh guru. Dengan kegiatan tersebut peserta didik bebas membaca buku yang ingin lebih dipahami. Kegiatan lain yang diselenggarakan seperti tafakur alam juga upaya untuk mendekatkan diri kepada Allah melalui alam terbuka, serta mendalami Islam disertai praktiknya. Untuk kegiatan tafakur alam sendiri biasanya dilakukan di tempat yang berbeda, seperti Coban Rondo, Sedudo, dan sebagainya. Dalam kegiatan tafakur alam terdapat kegiatan ceramah kerohanian, sholat fardhu berjama'ah diawal waktu, sholat sunnah (sholat dhuha, sholat taubat, sholat tahajud, sholat hajad, sholat witir, sholat taubat dan sebagainya), baca Al-Qur'an, istighosah/ do'a bersama, dan kegiatan penjelajahan yang membantu meningkatkan kecerdasan emosional dan spiritual peserta didik meningkat dengan signifikan.

\footnotetext{
${ }^{35}$ Nurdiansyah Junifar, "Pengaruh Kecerdasan Emosional, Kecerdasan Spiritual, Dan Perilaku Belajar Terhadap Tingkat Pemahaman Akuntansi," Jurnal Ilmu dan Riset Sekolah Tinggi Ilmu Ekonomi Indonesia (STIESIA) Surabaya, 5 (2015), 4.
} 
Adanya kegiatan Tafakur Alam diharapkan semakin mudah menggali dan mengembangkan potensi kecerdasan emosional dan spiritual peserta didik, karena dapat mengingat tujuan hidup, menjadikan ibadah rutin menjadi satu kebutuhan hidup, menanamkan rasa syukur terhadap nikmat yang telah diberikan oleh-Nya melalui ciptaanNya, serta melalui kegiatan kerja tim. Adanya kegiatan tafakur alam membuat peserta didik semakin baik dalam hal emosional dan spiritualnya, bahkan ada beberapa peserta didik non muslim ingin mengikuti kegiatan. Hal tersebut menandakan upaya guru PAI meningkatkan kecerdasan emosional dan spiritual sudah baik dengan dilakukannya berbagai pendekatan. Adanya kegiatan dari sosial hingga keagamaan diupayakan dengan maksimal meskipun kenyataannya masih ada beberapa hal yang perlu sedikit disempurnakan. Harus ada dari segala pihak mempunyai kesadaran bahwa masih ada yang perlu dilakukan perbaikan.

Upaya meningkatkan kecerdasan emosional dan spiritual peserta didik tidak hanya dilakukan di jam pelajaran, pada moment seperti adanya peringatan hari besar Islam dioptimalkan dengan diadakannya berbagai agenda yang sangat diminati peserta didik. Peserta didik sangat antusias dalam melakukan kegiatan PHBI, contohnya Maulid Nabi, 1 Muharram, pondok Ramadhan. Bagian Sie Kerohanian Islam (SKI) kompak meski terkadang ada beberapa yang harus diawasi. Dalam prakteknya ketika diadakan suatu kegiatan oleh SKI, guru hanya perlu mengecek bagian tertentu yang dianggap rawan seperti yang menjadi MC, qiro'ah dan seterusnya serta mengecek kesiapan panitia. Selain itu juga mengarahkan beberapa hal yang masih dirasa kurang. Tetapi secara total peserta didik sudah bisa bertanggung jawab terhadap kewajibannya.

Hasil dari upaya guru PAI dalam peningkatan kecerdasan emosional dan spiritual dilihat ketika evaluasi, secara umum perilaku dan akhlak sudah dinilai baik. Kepercayaan yang diamanatkan oleh guru baik melalui OSIS maupun Sie Kerohanian Islam (SKI) dilaksanakan dengan baik. Peserta didik juga menjadi pribadi yang memiliki rasa tanggung jawab, kepekaan sosial, serta sikap religius. Tolak ukur peningkatan kecerdasan emosional dan spiritual dilihat dari contoh kecil semakin baiknya perilaku peserta didik terutama terhadap bapak ibu guru, semakin banyak jamaah sholat dhuha dan dhuhur, semakin aktifnya kegiatan baik sosial maupun keagamaan. Tanggung jawab, serta disiplin dalam kegiatan sekolah dan organisasi ditambah lagi prestasi yang semakin baik.

Hal tersebut sama dengan pendapat Goleman yang merinci kecerdasan emosional kedalam lima unsur yaitu kesadaran diri (self awareness), pengendalian diri (self regulation), 
motivasi diri (self motivation), empati (empathy), kecakapan sosial (social skill). ${ }^{36}$ Untuk keerdasan yang berhubungan dengan diri sendiri Goleman menyebutnya degan istilah "EQ personal", sedangkan yang berhubungan dengan orang lain disebut "EQ sosial" EQ personal menjadi dasar bagi berkembangnya EQ sosial. ${ }^{37}$

Kecerdasan emosional peserta didik dilihat dari sikap mereka antar sesama seperti kepekaan sosial dan wujudnya bisa berupa mengadakan santunan, tanggap lingkungan, dan sebagainya. Sedangkan dari segi spiritualnya juga terlihat dari semakin penuhnya jama'ah sholat, bacaan al Qur'an yang semakin fasih, bahkan bisa mengikuti perlombaan keagamaan seperti debate PAI, lomba nasyid dan banyak lagi sebagai juara. Sikap emosional dan spiritual dilihat dari keseharian, contoh kecil jika ada sampah langsung terpanggil dalam dirinya untuk memasukkan didalam tempat sampah meski bukan sampahnya sendiri, ketika kalah dan menang dalam perlombaan baik didalam ataupun diluarsekolah menjadi pemacu semangat agar tetap bertahan serta semakin menambah wawasan, jika ada teman terkena musibah tanpa inisiatif dari guru dilakukan santunan, menjenguk teman yang sakit, dan banyak lagi. Dari spiritual bisa dilihat dari aktivitas setiap harinya sholat dhuha, sholat dhuhur secara berjama'ah dan menghindari masbuq dan rutin setiap hari tanpa penjadwalan bahkan juga melakukan sholat Idul Adha dan berqurban bersama - sama sambil mengingat ingat esensi dari kejadian qurban itu seperti apa sejarahnya, serta nilai - nilai ketawadhu'an.

\section{KESIMPULAN}

Upaya guru PAI dalam peningkatan kecerdasan emosional dan spiritual peserta didik di SMAN 1 Bojonegoro yaitu melakukan perencanaan pembelajaran dengan baik, mengoptimalkan kesiapan peserta didik dalam menerima materi, melakukan analisis dan evaluasi setiap pembelajaran, menggunakan bahasa persuasif, menanamkan berbagai pendekatan, menumbuhkan penghayatan dan semangat pengamalan terhadap ajaran agama, melakukan pengembangan pembelajaran PAI (Kajian malam Jum'at, Keputrian, Tafakur Alam, Jum'at bersih, literasi al-Qur'an, tahfidz, khotmil qur'an, istighosah, sholat sunnah, santunan, peringatan hari besar Islam dan seterusnya).

Faktor pendukung dalam peningkatan kecerdasan emosional dan spiritual peserta didik di SMAN 1 Bojonegoro yaitu adanya sumber daya manusia (SDM) dari peserta didik, guru, lingkungan, pihak sekolah mendukung segala kegiatan pembelajaran, kesadaran yang tinggi,

\footnotetext{
${ }^{36}$ Daniel Goleman, Emotional Intellegence.., 51 - 54.

${ }^{37}$ Herawati, "Emotional Spiritual...." 35.
} 
motivasi guru, pembiasaan - pembiasaan yang ditanamkan (peka terhadap lingkungan, tanggung jawab, dsb). Sedangkan faktor penghambat berasal dari faktor lingkungan asal peserta didik yang berbeda-beda dengan latarbelakang daerah yang berbeda maka perilaku dan karakter pun berbeda sehingga input peserta didik tidak dibatasi dari berbagai lingkungan yang berbeda-beda, selain itu faktor diri peserta didik sendiri, terkadang malas dan menganggap hal tersebut tidak penting karena menganggap seperti itu - itu saja. Padahal sangat penting dalam kehidupan sehari-hari dilingkungan masyarakat nanti. Untuk mengatasi penghambat tersebut guru memotivasinya. Adapun cara mengatasi faktor penghambat yaitu tidak mengurangi atau menghilangkan faktor pendukung dan mereduksi atau memperkecil terjadinya faktor penghambat, seperti melakukan koordinasi yang baik dengan berbagai pihak terkait, selalu berusaha istiqomah dalam kebaikan.

\section{DAFTAR PUSTAKA}

Agustian, Ary Ginanjar. Rahasia Sukses Membangun Kecerdasan Emosi Dan Spiritual. Jakarta: Arga Wijaya Persada. 2001.

Al Qur'an Terjemah Departemen Agama. Al-Qur'an Hafalan dan Terjemah. Jakarta: Almahira. 2015.

Ardana dkk. "Kecerdasan Intelektual. Kecerdasan Emosional. Kecerdasan Spiritual. Dan Kesehatan Fisik Untuk Memprediksi Prestasi Belajar Mahasiswa Akuntansi.” Jurnal Akuntansi Universitas Tarumanagara Jakarta. 17.September. 2003.

Arifin, HM. Filsafat Pendidikan Islam. Jakarta: Bumi Aksara. 2010.

Depdiknas. Kamus Bahasa Indonesia. Jakarta: Pusat Bahasa. 2008.

Goleman, Daniel. Emotional Intellegence terj. Jakarta: Gramedia Pustaka Utama. 2007.

Hamalik, Oemar. Kurikulum dan Pembelajaran. Jakarta: Bumi Aksara. 2003.

Aksara. 2008.

Pendidikan Guru Berdasarkan Pendekatan Kompetensi. Jakarta: Bumi . Psikologi Belajar dan Mengajar. Bandung: Sinar Baru Algensindo. 2004.

Herwati. "Emotional Spiritual Quotient dan Relevansinya terhadap Pendidikan Agama Islam.” Tesis. UIN Maulana Malik Ibrahim. Malang. 2016.

I.N. Thut dan Adams. Pola-Pola Pendidikan dalam Masyarakat Kontemporer. Yogyakarta: Pustaka Pelajar. 2005.

Ismail SM. Strategi Pembelajaran Agama Islam Berbasis PAIKEM. Semarang: Rasail Media Group. 2008.

Jalil, Abdul. Spiritual Entrepreneurship. Yogyakarta: Lkis. 2013.

Junifar, Nurdiansyah. "Pengaruh Kecerdasan Emosional. Kecerdasan Spiritual. Dan Perilaku Belajar Terhadap Tingkat Pemahaman Akuntansi." Jurnal Ilmu dan Riset Sekolah Tinggi Ilmu Ekonomi Indonesia (STIESIA). Surabaya. 5. 2015.

Kartilawati dan Mawaddatan Warohmah. "Profesionalisme Guru Pendidikan Agama Islam di 
Era Teknologi Informasi dan Komunikasi.” TA'DIB. 19 Juni. 2014.

Katni. Pengembangan Kurikulum PAI. Surabaya: Kopertais IV Press. 2015.

Keraf. Etika Lingkungan Hidup. Jakarta: Kompes Media Nusantara. 2010.

M. Shabir. "Kedudukan Guru Sebagai Pendidik.” AULADUNA. 2.Desember. 2015.

Moleong, Lexy J. Metodologi Penelitian Kualitatif.Bandung: Remaja Rosdakarya. 2009.

Muhaimin. Paradigma Pendidikan Islam. Bandung: Remaja Rosdakarya. 2004.

Naim, Ngainun. Menjadi Guru Inspiratif Memberdayakan Dan Mengubah Jalan Hidup Siswa. Yogyakarta: Pustaka Pelajar. 2009.

Najati, M. Usman. Al-Qur'an dan Psikologi. Terj. Ade Asnawi S.Jakarta: Asas Pustaka. 2001.

Nasih, Ahmad Munjin. Pendidikan Agama Islam. Bandung: Refika Aditama. 2013.

Nata, Abudin. Ilmu Pendidikan Islam. Jakarta: Kencana. 2010

Nazarudin Rahman. Manajemen Pembelajaran; Implementasi Konsep. Karakteristik dan Metodologi Pendidikan Agama Islam di Sekolah Umum. Yogyakarta: Pustaka Felicha. 2009.

Peraturan Menteri Pendidikan Dan Kebudayaan Nomor 60 Tahun 2014 Tentang Kurikulum 2013 Sekolah Menengah Atas/Madrasah Aliyah. 1.

Pusat Bahasa Depdiknas. Kamus Besar Bahasa Indonesia.Jakarta: Pusat Bahasa. 2008.

Ramayulis. Ilmu Pendidikan Islam.Jakarta: Kalam Mulia. 2011.

. Metodologi Pendidikan Agama Islam.Jakarta: Kalam Mulia. 2010.

Sahlan, Asmuan. Mewujudkan Budaya Religious di Sekolah Upaya Pengembangan PAI dari Teori ke Aksi. Malang: UIN Maliki Press. 2010.

Sukidi. Kecerdasan Spiritual; Mengapa SQ Lebih Penting dari IQ dan EQ.Jakarta: Gramedia Pustaka Utama. 2002.

Sukmadinata, Nana Syaodih. Metode Penelitian Pendidikan.Bandung: Remaja Rosdakarya. 2012

Undang - Undang Repubik Indonesia Nomor 14 Tahun 2005 tentang Guru dan Dosen. Jakarta: Redaksi Sinar Grafika. 2009.

Undang-Undang SISDIKNAS 2003. Jakarta: Sinar Grafika. 2003.

Zaini, Muhammad. Pengembangan Kurikulum : Konsep Implementasi Evaluasi dan Inovasi. Yogyakarta: Teras. 2009.

Zohar \& Marshall. Spiritual Quotient.SQ. terj.Bandung: Mizan. 2002.

Zuhairini. Metodik Khusus Agama Islam.Surabaya: Usaha Nasional. 2011. 